\title{
Comparative Study of Different Natural Coagulants for the Treatment of Grey Water with Conventional Alum
}

\author{
Shivangi Uliana, Brij Shah, Ishant Raj, Kavish Rathore, Roopika Nautiyal, Anantha Singh \\ Department of Civil Engineering, Pandit Deendayal Petroleum University, \\ Gandhinagar, Gujarat, India \\ anantha.singh@sot.pdpu.ac.in
}

\section{Extended Abstract}

The scarcity for portable water is a major problem in the developed countries like India. The increased waste demand may be managed by the treatment of grey water which consists of low pollutant concentration [1]. The major challenges in grey water treatment in order to meet all quality requirements are the fact that the quality of such effluent varies according to source, geographical location, demographics, level of occupancy and occupancy rate. The technology should be chosen based on these criteria along with the desired end use [2]. The grey water reuse has great potential in wide range of applications in domestic, commercial, institutional as well as industrial buildings [3]. Some of the inorganic coagulants used for coagulation are Alum (Aluminum Sulfate), Ferric Chloride, Polyaluminum Chloride (PACl) \& Aluminum Chlorohydrate $(\mathrm{ACH})$. These coagulants are not always available at a reasonable price, can leave undesirable large volumes of non-biodegradable sludge and also have serious effects on human body. The Cheeku is an indigenous, naturally derived coagulant, namely seed material from the multi-purpose tree Manilkara Zapota (commonly referred as Cheeku or Sapodilla) in the treatment of Grey water for Domestic Reuse [4,5]. Citrulluslanatus, commonly referred to as the watermelon seed is a naturally derived coagulant used in treatment of Grey Water for Domestic Reuse. It has long been valued for its refreshing fruits. These seeds contain proteins (Globulin, albumin, glutelin, vicinal); amino acids (arginine, isoleucine, leucine).

Studies have been carried out to determine the potential risks associated with the use of the seeds in water treatment. Till date, no study has concluded that there is evidence to suggest any acute or chronic effects on humans. The present study focused on the treatability of grey water using different freely available natural coagulants and to compare with the conventional inorganic coagulants. The grey water sample collected from the college hostel was used for the entire study. The freely available natural coagulant seeds like watermelon and Sapodilla seeds were used for the treatment. The parameters like $\mathrm{pH}$, TDS, turbidity, COD and BOD were analyzed and the concentrations were found to be $9.41,1630$ $\mathrm{mg} / \mathrm{l}, 305 \mathrm{NTU}, 4608 \mathrm{mg} / \mathrm{L}$ and $1543 \mathrm{mg} / \mathrm{l}$ respectively.

The seeds were obtained from different areas of Ahmedabad. The seeds were de-shelled (manually) and then were dried in sunlight for 10 hours. The kernel so obtained was crushed and then grinded to a fine powder by means of a domestic food blender. This Fine Powder so obtained is then kept in closed container. $2 \mathrm{~g}$ of this fine powder was taken and was added in $100 \mathrm{ml}$ distilled water. The suspension obtained was then stirred using a magnetic stirrer for 10 minutes. This was then stored in the refrigerator.

The seeds of Sapodilla as coagulant reported a turbidity reduced by $65 \%$, COD reduced by $35-45 \%$, BOD reduced by $50-60 \%$ at a coagulant concentration of $10 \mathrm{mg} / \mathrm{L}$. The concentration of watermelon seeds in grey water changes $\mathrm{pH}$ from 9.41 to 8.46 , turbidity from 305 NTU to 109 NTU. With the use of inorganic coagulant alum, a turbidity reduction from $305 \mathrm{NTU}$ to $122 \mathrm{NTU}$ at a concentration of $10 \mathrm{mg} / \mathrm{L}$ was observed.

The Watermelon seeds contain proteins (Globulin, albumin, glutelin, vicinal); amino acids (arginine, isoleucine, leucine) etc. which acts as coagulant and hence can be used in the treatment of Grey Water for Domestic Reuse purposes. Sapodilla and Watermelon seeds can be used as coagulating agent as they contain proteins and carbohydrates that have proved to be effective in the treatment of Grey Water [4]. The study proved that natural coagulants like Sapodilla and Watermelon seeds give better removal efficiency than alum for grey water treatment and can be used as a the alternative coagulant against the use of inorganic coagulants. 


\section{References}

[1] E. Eriksson, K. Auffarth, M. Henze, A. Ledin, "Characteristics of grey wastewater," Urban Water, vol. 4, no. 1, pp. 85-104, 2002.

[2] O. R. Al-Jayyousi, "Greywater reuse: towards sustainable water management," Desalination, vol. 156, pp. 181-192, 2003.

[3] P. M. Parameshwara-Murthy, B. M. Sadashiva Murthy, S. Kavya, "Greywater Treatment \& Reuse: A Technological Review," Global Journal for Research Analysis, vol. 5, no. 3, pp. 408-410, 2016.

[4] C. Saenz, E. Sepulveda, B. Matsuhiro. "Opuntiaspp mucilage's: a functional component with industrial perspectives," J Arid Environ, vol. 57, pp. 275-290, 2004.

[5] A. A. Al-Samawi, E. M. Shokralla, "An investigation into an indigenous natural coagulant," J. Environ. Sci. Health, Part A: Environ. Sci. Eng. Toxic Hazard. Subst. Control, vol. 8, 1881-1897, 1996. 